\title{
Early and mid-term results of transapical and right axillary artery cannulation for acute aortic dissection
}

\author{
T Terasaki , T Takano, T Fujii, K Komatsu, Y Ohtsu, Y Wada, T Seto, J Amano \\ From 23rd World Congress of the World Society of Cardio-Thoracic Surgeons \\ Split, Croatia. 12-15 September 2013
}

\section{Background}

We combined transapical cannulation (TAC) and right axillary artery cannulation (RAAC) for the repair of AAAD to reduce mortality and morbidity when malperfusion risk existed. We evaluated early and mid-term outcomes of AAAD repair with TAC and RAAC.

\section{Methods}

Between October 2009 and March 2012, 23 patients of AAAD received graft replacement with TAC and RAAC combination. Patients' age was $54.3 \pm 13.5$ years old. Preoperative malperfusion was presented in 16 patients (69.6\%). CPB was initially started with RAAC through the right armpit and right atrial drainage, and then TAC was applied through apex. We retrospectively investigated mortality and morbidity, and cardiac functions by echocardiography during hospital stay and once a year after operation.

\section{Results}

Total arch replacement was performed in all patients. Inhospital mortality was $4.3 \%$, and no patient developed intraoperative malperfusion. Intraoperative stroke occurred in 1 patient (4.3\%), and 3 patients (13.0\%) suffered from delayed stroke (10-24 days). These delayed strokes might be caused by cardiogenic thrombus, although no intracardiac thrombus was found. Mean ejection fraction was $66.1 \pm 10.9 \%$ in early periods and $73.1 \pm$ $8.7 \%$ mid-term periods. There was no LV asynergy or intra-cardiac thrombus in echocardiography of both studies of early and mid-term period.

* Correspondence: mayflyt@shinshu-u.ac.jp

Department of Cardiovascular Surgery, Shinshu University School of Medicine, Matsumoto, Japan

\section{Conclusions}

TAC with RAAC is a safe and effective procedure to reduce the risk of operation in acute type A aortic dissection. TAC may not affect cardiac functions although it might have potential risk of delayed stroke.

Published: 11 September 2013

\section{doi:10.1186/1749-8090-8-S1-042}

Cite this article as: Terasaki et al: Early and mid-term results of transapical and right axillary artery cannulation for acute aortic dissection. Journal of Cardiothoracic Surgery 2013 8(Suppl 1):O42.
Submit your next manuscript to BioMed Central and take full advantage of:

- Convenient online submission

- Thorough peer review

- No space constraints or color figure charges

- Immediate publication on acceptance

- Inclusion in PubMed, CAS, Scopus and Google Scholar

- Research which is freely available for redistribution

Submit your manuscript at www.biomedcentral.com/submit
C Biomed Central 